\title{
A different approach fot training student teachers using Communication and Information Technology (ICT)
}

\author{
Abad, Alida a and Rassetto, María ${ }^{a}$ \\ ${ }^{a}$ Facultad de Ciencias de la Educación - Universidad Nacional del Comahue \\ Irigoyen 2000, (CP8324) Cipolletti. Pcia Río Negro. Argentina.
}

\begin{abstract}
The aim of this research is to contribute to find new ways of teaching using the opportunities that Communication and information technology(ICT) give today. This contribution proposes a teaching strategy that allows students to think in a creative way and integrate technology in elementary school. This strategy consist in making the teacher student think themselves as inventors, detecting a need in society, designing and developing an invention that has not been yet patented. Creating marketing strategies for selling the product and presenting all this work in class for peers and teachers to evaluate. It was applied to student teachers during the period 2012- 2015 in a three month Seminary about the use of Technology at School. Surveys show that they are highly motivated with the methodology used at the Seminary and satisfied with the process. Most of them think that it is very useful when planning classroom work for children in elementary school. Presentations done for the seminary showed that the teacher students develop significant learning and many skills using information and communication technology (ICT) for learning purposes.
\end{abstract}

Keywords: Technology, significant learning, teachers' training. 


\section{Introduction}

Even though student teachers use technology in their everyday life and have access at very low cost to mobile handheld devices and wireless connectivity permanently this advantage does not always show creative ways of thinking about new teaching methods. Many research has been published concerning different strategies to integrate technology to teacher's training (Tondeur et al.,2012).

However class observation in elementary school and classwork planning point out that the integration of technology in education practice is seldom found.

The incorporation of a technology seminar in the teaching profession helps to overcome this deficiency. In this Seminary the aim was to improve teaching practices in a creative way and using full potential that can be developed using ICT.

Technology offers multiple uses such as presenting new materials that reorganize the information, build bridges to facilitate understandings, help recognize the information in different contexts(Litwin 2005).

The teacher students held a workshop where they were asked to position themselves as inventors. They had to detect a need of society that have not yet been satisfied and design and develop an invention to give answer to this problem. In this technological project various stages are highlighted:

- Detection of a problematic situation and defining the problem to be solved

- Analysis of the problem and its causes

- Search for alternative solutions

- Design an invention to solve the problem

- Search in Internet for similar inventions, identifying reliable pages.

- Identify improvements that can be made to existing inventions on the market or think of something absolutely different and new that does not exist yet in market

- Design the invention using a proper soft design like Tinker cad or similar

- Develop the invention and make it work

- Think of the commercial target and shape a commercial to sell the product using video editing programs like Movie Maker o similar

- Make a presentation as a final work for peers and teachers using any on line presentation program like prezi or slide share

- Upload presentation on moodle platform

In the required work three stages can be clearly seen as mentioned by Gay (2012)

- study phase

- creative phase 
- $\quad$ execution phase

In the first stage the student teachers develop a wide vision of the problem, analytical skills, comprehensive approach and inductive reasoning.

In the second stage creativity, ability to synthesize, subjective judgment and deductive reasoning.

In the third stage, organizational capacity, planning and evaluation.

During all this stages information and comunication technology is been used for developing new ways of learning and teaching. This methodological strategy aims to encourage searching and access to information, knowledge and skills for specific needs in specific contexts of use, where those resources are immediately relevant and useful. Things will be learned better and retained more effectively when they are learned in contexts of use - uses that are of intrinsic importance to the learner in a place, time, and circumstance that matters to them. (Burbules 2014)

Research shows that since the introduction of technology in classroom practice, the way students think about their own learning has changed and also the way knowledge is constructed. Also the way teachers plan their classes when they are critical of the new learning environments is very different. (Lion 2005).

This Seminary gives the student teachers the opportunity of thinking about the process of learning and teaching in a different way.

Surveys show that they develop flexible ways of thinking about technology, design and learning. They also become aware of the importance of the teaching role when planning activities leading to significant learning and the need to think about motivation for classroom work with children.

The role of the teacher is still crucially important in helping learners organize and integrate their learning in meaningful ways; in helping learners to sequence learning opportunities; in helping to inspire, motivate, and model learning as an active endeavor. (Burbules 2014)

\section{Methods}

In order to know the impact of this new methodological strategy developed during the three month Technology Seminary, surveys were administrated at the end of the workshop, during years 2014 and 2015. The Survey was given in class to all the students. All of them female. In 2014 we had 62 surveys and in 2015 there were 68. 
The aim of this research is the analysis of numerous variables related to the skills developed by the student teachers and also how these skills can help them develop creative ways to plan classes.

The survey included the following topics:

Table 1. Skills developed by the teachers students during the Technology Seminary

\begin{tabular}{|l|l|}
\hline Development level for the following skills & $\begin{array}{l}\text { Consider } \mathbf{1} \text { is very low } \\
\text { and } \mathbf{4} \text { is very high }\end{array}$ \\
\hline Finding data in internet in trustful pages & \\
\hline Interpreting data and using data to solve problems & \\
\hline Learning new things & \\
\hline Interest in things you didn't think about before & \\
\hline Design what you are going to do using specific software & \\
\hline Developing a prototype & \\
\hline Thinking marketing strategies for commercials. & \\
\hline Using specific software to edit videos for commercials & \\
\hline Communicate ideas to peers using on line presentation forms. & \\
\hline
\end{tabular}

Table 2. Elements concerning personal aspects of the teachers students

\begin{tabular}{|l|l|}
\hline $\begin{array}{l}\text { Satisfaction level with the development of personal } \\
\text { aspects }\end{array}$ & $\begin{array}{l}\text { Consider } \mathbf{1} \text { is very low and } \mathbf{4} \text { is } \\
\text { very high }\end{array}$ \\
\hline Your creativity & \\
\hline Your motivation & \\
\hline Your confidence to plan classroom work using ICT & \\
\hline
\end{tabular}




\section{Results and Discussion}

The result of the 2014 and the 2015 sureveys all together were as follows:

- For skills developed

Finding data in internet in trustful pages

Interpreting data and using data to solve problems

Learning new things

Interest in things you didn't think about before

Design using specific software

Developing a prototype

Thinking marketing strategies for commercials.

Using specific software video edition

Communicate ideas to peers using

on line presentation forms

\section{- For personal aspects}

\section{Creativity}

Motivation

Confidence to plan classroom work using ICT
$87 \%$ consider very high none very low

$52 \%$ very high $9 \%$ very low

$72 \%$ very high $5 \%$ very low

$63 \%$ very high none very low

$70 \%$ very high $3 \%$ very low

$85 \%$ very high none very low

$62 \%$ very high $3 \%$ very low

$86 \%$ very high none very low

$81 \%$ very high $2 \%$ very low

$74 \%$ consider very high none very low

$91 \%$ very high, none very low

$47 \%$ very high, $4 \%$ very low

The percentages shown above tell us that most of the teacher students think that have improved their skills and also their personal aspects have been satisfied. The items with the highest percentage skills are related to actions they usually practice in every day life and this strategy only helped them improve. It is interesting to point out though that developing a prototype is not frecuently done at home but has probably a high punctuation because it was amusing for them inventing something new. Surprisingly interpreting data to solve problems was very low punctuated by a lot fo students eventhough all could solve the main problem that was to make a prototype work. This probably has to do with a different vision of what a problem solving means in regular classes. 


\section{Conclusions}

The feedback provided by the students surveys and teachers observation of the final work indicate that this approach for training student teachers in the use of technology for educational purposes is convenient and needs to be improved. There are still many questions about what skills must be developed for training future teachers and how may ICT be part of new learning environments.

The incorporation of ICT in teacher education along with good practices, will allow future teachers to make systematic use of them and innovate in their classrooms. (España, Foresi 2009)

The use of new technologies in education is fully justified if we consider that one of the basic goals of education should be the preparation of the two children to be citizens of a pluralistic, democratic and technologically advanced society ( Perales; Cañal de León 2002).

\section{References}

Burbules, N. (2014) Ubiquitous Learning: New Contexts, New Processes. Queens University Education Letter (PP) 18-20.

Burbules, N.; Callister T. (2000) The Risks and Promises of Information Technologies for Education.Westview Press, EEUU.

España, A.; Foresi M. (2009) Las prácticas y el desarrollo profesional ante las tecnolog \{ias de la información y de la comunicación Cap VI en Sanjurjo Liliana Los dispoisitivos para la formación en las prácticas profesionales ed Homo Sapiens Rosario Argentina

Gay, A. (2012) La Educación tecnológica. Editorial Brujas. Córdoba, Argentina.

Litwin, E. (2005) Tecnologías Educativas en tiempos de Internet Cap 1 La tecnología en el debate didáctico contemporáneo. Amorrortu Editores. Madrid, España.

Lion, C. (2005) Nuevas maneras de pensar tiempos, espacios y sujetos en Litwin, E. (Compiladora) Tecnologías Educativas en tiempos de Internet. Amorrortu Editores. Madrid, España.

Perales Palacios, F. ; Canal de León, P. didáctica de lasw Ciencias Experimentales Editorial Marfil, Alcoy España.

Tondeur, J., van Braak, J., Sang, G., Voogt, J., Fisser, P., \& Ottenbreit-Leftwich, A. (2012). Preparing pre-service teachers to integrate technology in education: A synthesis of qualitative evidence. Computers \& Education, 59(1), 134-144. 